\title{
Kampen mot tuberkulose
}

\author{
I 1993 introduserte Verdens helseorganisasjon et nytt behandlingspro- \\ gram mot tuberkulose. En av komponentene er at inntak av medika- \\ menter skal observeres av helsepersonell. Det ble tidlig hevdet at pro- \\ grammet var en suksess, men vi har påvist at kravet om daglig oppmøte \\ ved klinikken kan innebære store kostnader for pasienten og familien. \\ Enkelte har opplevd å bli nektet medisiner fordi de ikke klarer å oppfylle \\ kravene som behandlingsopplegget stiller.
}

\author{
Mette Sagbakken \\ mette.sagbakken@medisin.uio.no \\ Avdeling for allmenn- og samfunnsmedisin \\ Institutt for helse og samfunn \\ Universitetet i Oslo \\ Postboks 1130 Blindern \\ 0318 Oslo \\ Jan C. Frich \\ Avdeling for helseledelse og helseøkonomi \\ Institutt for helse og samfunn \\ Universitetet i Oslo \\ Gunnar A. Bjune \\ Avdeling for allmenn- og samfunnsmedisin \\ Institutt for helse og samfunn \\ Universitetet i Oslo
}

Årlig rammes 9,2 millioner mennesker av tuberkulose og 1,7 millioner dør. Antall nye tilfeller av tuberkulose øker globalt. Tuberkulose skiller seg fra en del andre sykdommer med høy dødelighet ved at det finnes effektiv behandling $(1,2)$. Ved å behandle mennesker med aktiv sykdom kan smitte forebygges og byrden av sykdommen reduseres. I et globalt perspektiv er de fleste pasienter med tuberkulose unge, og medisinsk behandling fører vanligvis til at pasienter oppnår full førlighet og vender tilbake til et aktivt og økonomisk produktivt liv. Tuberkulose regnes derfor som en av de mest kostnadseffektive sykdommene å behandle (3).

\section{Global krise}

Verdens helseorganisasjon karakteriserte i 1993 økningen i tuberkulose som en «global krise». Man så en økning i antall tuberkulosetilfeller både i utviklingsland og $\mathrm{i}$ industrialiserte land samt en økning i antall multiresistente tilfeller (2). Utbrudd av hivrelatert tuberkulose i New York i slutten av 1980- og tidlig 90-årene var en viktig kilde til fornyet oppmerksomhet og frykt for sykdommen. Fremveksten av tuberkulose har flere og sammensatte årsaker, men hivepidemien har hatt en akse- lererende effekt på smittespredningen pga. oppbluss av tuberkulose hos pasienter med immunsvikt. Mange tilfeller av ufullstendig behandling har medført resistensutvikling og som en følge av det; flere smittebærere (2). Sen diagnostikk er en annen årsak til at pasienter forblir smittespredere over en lang periode.

\section{Fattigdom og befolkningstetthet}

Om lag en tredel av verdens befolkning er smittet av tuberkulose, men bare $10 \%$ av disse blir syke. Hvem rammes av sykdommen? $95 \%$ av alle tilfeller og $98 \%$ av alle dødsfall av tuberkulose finner sted i utviklingsland (3). Også innad i fattige land rammer tuberkulose de dårligst stilte. I slumområder i Delhi og Calcutta rammes 50 av 1000 , sammenliknet med tre av 1000 utenfor slummen (4). Fattigdom, underernæring og høy befolkningstetthet har lenge vært ansett som de viktigste predisponerende faktorene for tuberkulose (5). Forekomsten hadde lenge vært på kraftig retur i Norge da antibiotika ble tatt $\mathrm{i}$ bruk som behandling

(2). Denne utviklingen skyldtes i hovedsak den generelle velstandsutviklingen (6).

\section{Tilgjengelighet av helsetjenester}

Tuberkuloserammede lever i all hovedsak i områder preget av liten velferdsutvikling. Det medfører mange fattigdomsrelaterte problemer og begrensninger. En rekke studier viser at hovedårsaken til sen diagnostisering blant tuberkulosepasienter er at helsetjenestene i mange fattige land er utilgjengelige eller dyre $(7,8)$. Selv om tuberkulosemedisiner kan være gratis, koster det å ta bussen til en klinikk, å utføre undersøkelser og å være borte fra arbeidet. I samfunn med få rettigheter som arbeidstaker og hvor det fattigste segmentet av befolkningen sjelden nyter fordelen av fast ansettelse, kan tid brukt til diagnostiske undersøkelser være det som koster deg jobben.

\section{Observert behandling}

I 1993 introduserte Verdens helseorganisasjon behandlingsprogrammet DOTS (directly observed treatment, short course), som først ble utprøvd i India (1). Målet var å møte tuberkuloseproblemet på en mer effektiv måte, og ikke minst forebygge utvikling av resistens mot medikamenter. En av komponentene i programmet er direkte observert terapi (DOT), som innebærer at inntak av medikamenter skal observeres av helsepersonell. Det ble tidlig hevdet at DOTS-programmet var en suksess, ikke minst fordi programmets øvrige komponenter har sikret kunnskapsbasert medikamentell behandling, sikker tilgang på medisiner, mikrobiologisk diagnostikk samt bedret registrerings- og rapporteringsrutiner. DOTS har ikke minst ført til økt oppmerksomhet mot bekjempelse av tuberkulose.

Programmet er blitt kritisert for manglende søkelys mot utvikling av nye vaksiner og medisiner og for å være et overforenklet tiltak basert på konvensjonelle metoder (9). Direkte observert terapi, av mange oppfattet som essensen av DOTS, har vært problematisert ut fra et etisk perspektiv og et menneskerettighetsperspektiv (10). Verdens helseorganisasjons beslutning om å anbefale en streng og universell håndhevelse av direkte observert terapi ble bestemt på grunnlag av noen få kontrollerte studier, og man tok i liten grad inn over seg at programmet skulle introduseres i helt ulike sosiale, økonomiske og kulturelle kontekster. Det er hevdet at man har vært lite opptatt av om implementeringen av direkte observert terapi har vært brukervennlig, i hvilken grad klinikker og helsepersonell er kultursensitive og hvorvidt krav om daglig klinikkbasert behandling er berettiget (11). Enkelte har hevdet at introduksjon av begreper som «global krise» har vært brukt som begrunnelse for tiltak som påkaller skyld og som fratar eller begrenser enkeltgruppers rettigheter uten tilstrekkelig grunnlag (12).

\section{Byrde for pasientene?}

Randomiserte kontrollerte studier viser at behandlingsresultatene ved tuberkulose $\mathrm{i}$ liten eller ingen grad påvirkes av om medisinene er tatt ved selvadministrering eller ved observert inntak (13). Forskning viser at direkte observert behandling kan være en stor byrde, særlig for de fattigste pasientene $(14,15)$. I en studie i Etiopia har 


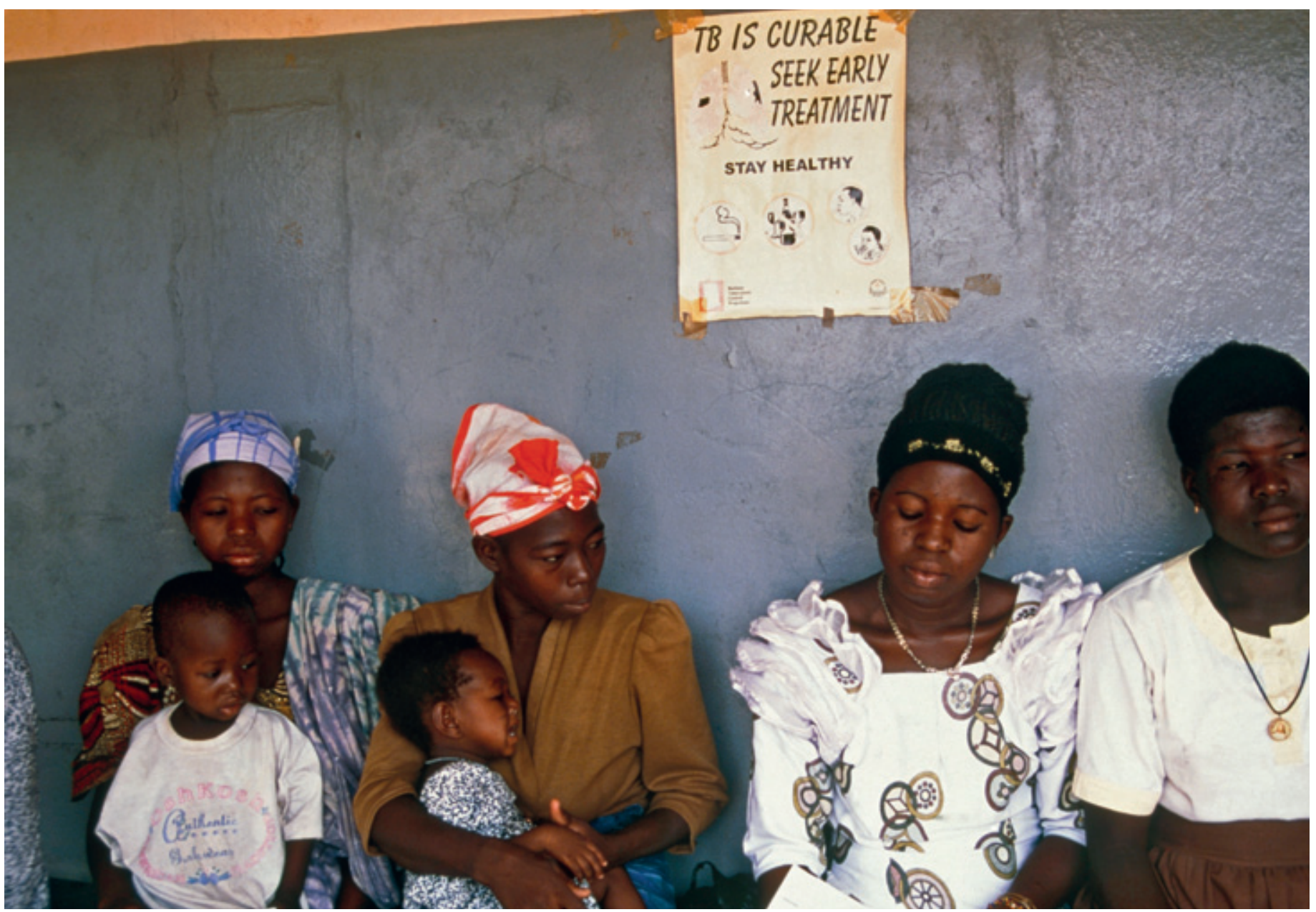

Illustrasjonsfoto @ Science Photo Library/GV-Press/NordicPhotos

vi påvist at kravet til pasienten om daglig oppmøte ved klinikken innbærer store direkte og indirekte kostnader i form av utgifter til transport, bruk av tid til reise og venting på klinikker, tap av arbeid eller muligheten til å arbeide, økende fattigdom, tap av bolig, sult og desperasjon (14). Husholdinger kan miste inntektsgrunnlaget fordi familiemedlemmer daglig må bistå med å støtte eller bære pasienter til klinikken. Vi fant eksempler på at de mest marginaliserte og maktesløse opplever å bli nektet medisiner fordi de ikke klarer å oppfylle kravene som behandlingsopplegget stiller (14).

\section{Ulikheter i helsevesenet}

Tuberkulosekontrollarbeidet avspeiler sterk vilje til å demme opp mot en utvikling med økende resistens mot antituberkuløs behandling. Multiresistent tuberkulose representerer en trussel også for mennesker i den mer privilegerte del av verden. I for liten grad gjenspeiler arbeidet en vilje til å forholde seg til tuberkulosens hovedårsaker: fattigdom og urettferdig fordeling. Til en viss grad kan helsevesenet bidra til å forsterke eksisterende ulikheter, ved at de mest marginaliserte ikke makter å leve opp til kravene i behandlingsopplegget og dermed avskjæres fra videre oppfølging. En forutsetning for å utrydde tuberkulose er at vi tar i betraktning forholdene som disponerer for sykdommen samtidig som vi forsøker å tilpasse behandlingen slik at ulikhetene som disponerer for sykdommen ikke forsterkes ytterligere i pasientens møte med helsevesenet. Medisinen har en viktig oppgave i å synliggjøre og dokumentere sosiale, økonomiske og politiske vilkår for helse (16).

\section{Uetisk behandling?}

Tuberkulosekontroll som ikke retter søkelyset mot de sosiale forhold som disponerer for tuberkulosesmitte og oppbluss av sykdommen, og som i sin praksis forsterker fattigdomsrelaterte problemer for de svakeste, er feilslått. Slike programmer har dessuten en uetisk og diskriminerende karakter. Er det rimelig at pasientene skal godta en lang daglig reise, med tap av inntekt og arbeidsmuligheter, fordi helsepolitikere har bestemt at medisinen skal tas under påsyn av helsepersonell - uten at evnen til å utføre dette selv eller andre mer fleksible støtte- eller påminnelsesordninger blir vurdert? Hvordan opplever vi som pasienter slike prosedyrer $i$ den vestlige verden? Mange ville nok vært svært kritiske til formynderholdningen og ha etterlyst større interesse for pasienters autonomi. For å imøtekomme noen av disse innvendingene har Verdens helseorganisasjon anbefalt implementering av "communitybased DOT» som en del av nasjonale tuberkuloseprogrammer (17). En nyere gjennomgang av litteraturen viser at organiseringen av tuberkulosebehandlingen i form av direkte observert behandling fremdeles gjør det vanskelig for pasienter å gjennomføre behandlingsopplegget (15).

\section{Utviklingen i Norge}

Økt migrasjon har resultert i at tuberkulose igjen er blitt en viktig folkehelseutfordring i Norge $(18,19)$, og forsinket diagnose er et problem blant pasienter med tuberkulose $i$ vårt land (20). I en studie blant pasienter med tuberkulose som har innvandret fra Somalia og Etiopia til Norge rapporterte to tredeler av en gruppe på 22 pasienter om en langvarig og forsinket diagnostisk prosess (21). Langvarig hoste uten tilhørende symptomer som vekttap og slapphet, milde, diffuse symptomer og en følelse av ikke å være et sannsynlig offer for tuberkulose bidro til at pasientene ventet med å søke helsehjelp. Etter å ha kontaktet helsetjenesten kunne det likevel ta måneder, i enkelte tilfeller år, før diagnosen ble stilt. I tilfeller 
der pasienten selv mistenkte tuberkulose, opplevde flere at helsepersonell ikke tok dette på alvor. Noe av forklaringen på dette er nok at norsk helsepersonell i liten grad er oppmerksom på verken typiske eller atypiske symptomer på tuberkulose.

Svært få vestlige land ser ut til å ha implementert en universell praksis av direkte observert terapi. I Norge ble dette innført som en del av behandlingen av alle tuberkulosepasienter i 2003 og praktiseres i hovedsak ved at den kommunale hjemmetjenesten bringer medisinene hjem til pasientene. Dette gir sannsynligvis mindre belastninger i form av utgifter og tap av tid. Det er gjort lite forskning på hvordan pasienter opplever behandling ved direkte observert terapi i ressursrike deler av verden. På dette området trenger vi derfor mer kunnskap.

\section{Avslutning}

Tuberkulose kan ikke bekjempes gjennom bedre medikamentell behandling alene. Tidlig diagnostikk, helsetjenestens organisering og måten behandlingen gis på er viktige faktorer for om pasienter er i stand til å gjennomføre et krevende behandlingsopplegg. I tillegg er det nødvendig å rette oppmerksomheten mot grunnleggende samfunnsforhold som forårsaker sykdommen.

Oppgitte interessekonflikter: Ingen
Litteratur

1. Verdens helseorganisasjon. Global tuberculosis control: surveillance, planning, financing. Genève: WHO, 2009. www. who.int/tb/publications/global report/2009/en/ (27.1.2010).

2. Folkehelseinstituttet. Tuberkulose. www.fhi.no/ eway/default.aspx?pid=233\&trg=MainLeft_5799 \&MainArea_5661=5799:0:15,1904:1:0:0::0:0\&Main Left $5799=5544: 56120:: 1: 5800: 122::: 0: 0$ (27.1.2010)

3. Murray CJ, Styblo K, Rouillon A. Tuberculosis in developing countries: burden, intervention and cost. Bull Int Union Tuberc Lung Dis 1990; 65: $6-24$.

4. Ogden J, Rangan S, Uplekar M et al. Shifting the paradigm in tuberculosis control: illustrations from India. Int J Tuberc Lung Dis 1999; 3: 855-61.

5. Røttingen J-A. Frich JC. Fremveksten av infeksjonssykdommer - en konsekvens av ulikheter. Tidsskr Nor Lægeforen 2001; 121: 841-4.

6. Lönnroth K, Jaramillo E, Williams BG et al. Drivers of tuberculosis epidemics: the role of risk factors and social determinants. Soc Sci Med 2009; 68: 2240-6.

7. Storla DG, Yimer S, Bjune GA. A systematic review of the delay of diagnosis and treatment of tubercu losis. BMC Public Health 2008; 8: 15

8. Sagbakken M, Frich JC, Bjune G. Perception and management of tuberculosis symptoms in Addis Abeba, Ethiopia: A qualitative study. Qual Health Res 2008; 18: 1356-66.

9. Ogden J, Walt G, Lush L. The politics of «branding» in policy transfer: the case of DOTS for tuberculosis control. Soc Sci Med 2003; 57: 179-88.

10. Pronyk P. Porter JD. Public health and human rights: the ethics of international public health interventions for tuberculosis. I: Porter JD, Grange $J$, red. Tuberculosis: an interdisciplinary perspective. London: Imperial College Press, 1999: $99-120$.

11. Lienhardt C, Ogden JA. Tuberculosis control in resource-poor countries: have we reached the limits of the universal paradigm? Trop Med Int Health 2004; 9 : 833-41.

12. Lupton D. The imperative of health: public health and the regulated body. London: Sage, 1995.

13. Volmink J, Garner P. Directly observed therapy for treating tuberculosis. Cochrane Database Syst Rev 2007; nr. 4: CD003343

14. Sagbakken M, Frich JC, Bjune G. Barriers and enablers in the management of tuberculosis treatment in Addis Ababa, Ethiopia: a qualitative study. BMC Public Health 2008; 8: 11

15. Munro SA, Lewin SA, Smith HJ et al. Patient adherence to tuberculosis treatment: a systematic review of qualitative research. PLoS Med 2007; 4: e238

16. Frich JC. Helse og helserettigheter. Tidsskr Nor Lægeforen 2006; 126: 196-7.

17. Community contribution to TB care: practice and policy. WHO/CDS/TB/2003.312. Genève: Verdens helseorganisasjon, 2003.

18. Harboe M. Tuberkulosens nye ansikt i Norge. Tidsskr Nor Lægeforen 2006; 126: 2682-3.

19. Steen TW, Drage M, Solum JA. Hvordan bekjempe hiv, tuberkulose og malaria? Tidsskr Nor Legeforen 2009; 129: 2504-8

20. Farah MG, Rygh JH, Steen TW et al. Patient and health care system delays in the start of tuberculosis treatment in Norway. BMC Infect Dis 2006; 6 : 33.

21. Sagbakken M, Bjune GA, Frich JC. Experiences of being diagnosed with tuberculosis among immigrants in Norway - factors associated with diagnostic delay: a qualitative study. Scand J Public Health; doi: 10.1177/1403494809357101.

Manuskriptet ble mottatt 28.1. 2010 og godkjent 4.2. 2010. Medisinsk redaktør Siri Lunde. 